out as leading institutes and are under the direct jurisdiction of the State Planning Committee. The research carried out in these institutes is in addition to that at the universities, technical colleges and factory laboratories. One of the basic means of training scientists in the Soviet Union is by means of part-time graduate work for industrial employees at colleges, universities and research centres, and by independent research on a chosen problem. It is worth noting that the part-time postgraduate students are paid monthly allowances, while 80 per cent of undergraduate full-time students receive Government grants; of these 50 per cent live in dormitories attached to the institutions of higher education. According to recent Soviet statisties 320,000 students graduated in 1961 from higher educational establishments, this total including 120,000 engineers. More than two and a half million, full-time and part-time, are undergoing a universitystandard education at present and the number of full-time university students is 280,000 .

In spite of all the upheavals, the Russians have consistently devoted enormous resources to education of their young people as scientists and technologists. The rapid growth of Soviet industry has been partly made possible by the enormous number of trained specialists. For every ton of steel the Russians produce every year, they educate at least ten times as many metallurgists as trained in Britain; by 1965 the U.S.S.R. hopes to make more steel than the whole of Western Europe put together. At the same time the Soviet Union supplies technologists - those emissaries of our modern age-to the uncommitted nations. This growth appears to increase very rapidly, for it is found--this is a general observation applicable to most countries-that the rate at which the number of scientists and technologists increases during a decade is proportional to the number of such men then alive. This emphasis on technology is shown by the observation that in 1954 the numbers of first degrees in pure science and technology in the Soviet Union were per million of population 56 and 280 respectively; the corresponding figures for Britain were 105 and 57 respectively.

[To be continued]

\title{
OBITUARIES
}

\section{Prof. W. B. Brierley}

IN the present-day world of specialization in narrower and narrower fields it is becoming increasingly difficult for a man, however able, to encompass in his knowledge and experience the broad acres of learning in his own larger territory. The days of the encyclopædic botanistsBower, Farmer, Oliver, Weiss and Strasburger, to mention only a few of the great names of the past - are virtually over. In the rat-race of mid-twentieth century research a man must be so deeply involved in his own speciality that it is impossible for him to comprehend the rest of the huge field, an area which, in any event, like the expanding universe, is increasing in size and complexity at an accelerating pace.

Trained under F. E. Weiss in this tradition of breadth of vision, William Broadhurst Brierley belongod to this school. Although his own field, by force of circumstance, was that of mycology and plant pathology, he never lost his interest in the whole area, and he preached always a doctrine of 'holism', that an understanding of the plant in disease and of its pathogen could only come through a knowledge of the plant in health, acted on and reacting with its environment.

Born in Manchester in 1889, his early life was a struggle against poverty, a struggle which coloured and conditioned his life-long attitude to human problems and relationships. Innate in him was a passionate feeling for the underdog, for the 'have-nots'; he did good by stealth and only his olosest intimates knew of his good works. As a young man he gave up much time to the Workers' Educational Association, and it was perhaps largely due to his activities here that he developed his gift for lucid and striking exposition. One of his lectures to the Workers' Educational Association, entitled "Too Many Fingers and Too Many Toes", was a brilliant explanation of genetical principles admirably suited to his audience. He studied deoply in the colour problem, in those days mainly that of the Negro in the United States, and he wrote and spoke feelingly on the subject.

Ho worked his way through his degree course in the University of Manchester, repeatedly winning prizes and onding with a brilliant first and a graduate research scholarship. He was a lecturer in applied botany at Manchester during 1912-15 and in the last-named year he was appointed to a research post in the newly established
Laboratory of Plant Pathology at Kew. He was released to serve in the Artists' Rifles but was invalided out in 1916 and returned to Kow.

In 1918 the Institute of Plant Pathology was founded at Rothamsted Experimental Station, and Brierley was appointed first head of the Department of Mycology, where he was for long associated with A. D. Imms, head of the Department of Entomology. Here he worked on the complex genus Botrytis, on which he intended to prepare a definitive monograph, though his return to the academic field later prevented its completion. At Rothamsted he was the stimulating and enthusiastic leader of a team of virologists and mycologists who made many contributions to plant pathological knowledge.

His true love and greatest ability lay, as has been said, in exposition and his career stabilized when, in 1932, he was elected to the chair of agricultural botany in the University of Reading, left vacant by the retirement of Prof. John Percival. Here his gift for teaching and his qualities of human understanding resulted in the further expansion and fame of a Department noteworthy for its unity and for the quality of its graduates. His outstanding characteristics were his sense of service and his scientific integrity; for twenty-five years he served as honorary editor of the Annals of Applied Biology and earned for the journal the reputation of being one of the best-edited in the world. He would never pass slip-shod writing or loose argument, and though indifferent authors were sometimes offended by his extensive editing, they always came to recognize the great value of his advice.

His own writings were many, on such diverse subjects as the species concept, disease resistance in plants, and the training of botanists, while for many years he contributed the section on progress in the biological sciences to the Annual Register. His able translation in collaboration with his wife, incidentally herself a distinguished psychoanalyst, of Prof. Ernst Gäumann's Principles of Plant Infection made available a great classic to English students.

He retired in 1955 to live in the Lake District, where he became an enthusiastic gardener and kept open house for his old friends and students, who came from all parts of the world to enjoy again the pleasure of hard-fought, but always courteous, discussion and argument. His epitaph might well be: 'he loved people'.

R. H. Stodghton 